\title{
EFFECT OF $\alpha$-TOCOPHEROL AND ASCORBIC ACIDS ON PERFORMANCE AND BLOOD IMMUNITY PROFILE OF MALE NATIVE MUSCOVY DUCK
}

\author{
E. Tugiyanti ${ }^{1}$, T. Yuwanta ${ }^{2}$ Zuprizal $^{2}$, Rusman $^{2}$ and Ismoyowati ${ }^{1}$ \\ ${ }^{1}$ Faculty of Animal Science, Jenderal SoedirmanUniversity, \\ Jl. Dr. Soeparno No. 60, Purwokerto 53122 - Indonesia \\ ${ }^{2}$ Faculty of Animal Science, Gadjah Mada University, \\ Jl. Fauna 3, Bulaksumur, Yogyakarta - Indonesia \\ Corresponding E-mail: tugiyanti.elly@gmail.com
}

Received April 06, 2016; Accepted June 08, 2016

\begin{abstract}
ABSTRAK
Penelitian ini bertujuan mengkaji pengaruh $\alpha$-tokoferol dan asam askorbat terhadap performan dan profil imunitas darah entok. Materi penelitian menggunakan 84 ekor entok jantan umur sembilan minggu. Penelitian dilaksanakan berdasarkan rancangan acak lengkap dengan 7 perlakuan yaitu E0C0: pakan basal tanpa diberi $\alpha$-tokoferol dan asam askorbat, E400: pakan basal+400 IU $\alpha$-tokoferol, E600: pakan basal+600 IU $\alpha$-tokoferol, C400: pakan basal+400mg asam askorbat, C600: pakan basal+600mg asam askorbat, E200C200: pakan basal $+200 \mathrm{IU} \alpha$-tocopherol+200mg asam askorbat dan E300C300: pakan basal+300 IU $\alpha$-tokoferol+300mg asam askorbat. Tiap perlakuan diulang sebanyak 4 kali dan setiap unit percobaan terdiri 3 ekor. Variabel yang diamati adalah bobot badan, konsumsi pakan, konversi pakan, jumlah leukosit, packed cell volume (PCV,) total protein plasma (TPP), basofil, eosinofil, heterophyl, monosit, limfosit, dan rasio heterofil/limfosit (H/L). Hasil penelitian mengindikasikan bahwa perlakuan E0C0, E400, E600, C400, C600, E200C200 dan E300C300 berpengaruh tidak nyata terhadap bobot badan, konsumsi dan konversi pakan, berpengaruh nyata terhadap nilai PCV, tetapi tidak berpengaruh terhadap TPP. Perlakuan E0C0, E400, E600, C400, C600, E200C200 dan E300C300 berpengaruh nyata terhadap jumlah leukosit, persentase heterofil dan limfosit, tetapi tidak berpengaruh terhadap persentase eosinofil, monosit dan rasio $\mathrm{H} / \mathrm{L}$. C400 menghasilkan persentase $\mathrm{PCV}$, heterofil dan rasio $\mathrm{H} / \mathrm{L}$ tertinggi. C600 menghasilkan jumlah leukosit tertinggi. Suplementasi asam askorbat $400-600 \mathrm{mg} / \mathrm{kg}$ pakan dapat memperbaiki profil imunitas tetapi tidak memperbaiki performan entok.
\end{abstract}

Kata kunci: daya tahan tubuh, Entok, tocopherol, asam askorbat

\begin{abstract}
The purpose of the research was to assess the effect of $\alpha$-tocopherol and ascobic acids on the performance and immunity blood profile of male native Muscovy duck. The materials used were 84 male Muscovy ducks at 9 weeks old. The research used completely randomized design with 7 treatments. The treatments were E0C0 : basal diet without $\alpha$-tocopherol and ascobic acids, E400: basal diet $+\alpha$-tocopherol 400IU, E600: basal diet $+\alpha$-tocopherol 600IU, C400: basal diet + ascorbic acid $400 \mathrm{mg} / \mathrm{kg}$, C600: basal diet+ascorbic acid $600 \mathrm{mg} / \mathrm{kg}$, E200C200: basal diet $+\alpha$-tocopherol $200 \mathrm{IU}+$ ascorbic acid $200 \mathrm{mg} / \mathrm{kg}$, and E300C300: basal diet $+\alpha$-tocopherol $300 \mathrm{IU}+$ ascorbic acid $300 \mathrm{mg} / \mathrm{kg}$. Each treatment was repeated 4 times and each replication consisted of 3 ducks. The observed variables were body weight, feed consumption, feed conversion ratio, packed cell volume (PCV), total of plasma protein (TPP), leucocyte count, basophil, heterophil, eosinophil, monocyte, lymphocytes
\end{abstract}


count and heterophil/lymphocyte $(\mathrm{H} / \mathrm{L})$ ratio of Muscovy duck. The result indicated that E0C0, E400, E600, C400, C600, E200C200 and E300C300 had no significant difference in body weight, feed intake and feed conversion. There were significant effects on PCV, leucocyte count, percentage of heterophil and lymphocytes, but had no significant effect on eosinophil, monocyte and the $\mathrm{H} / \mathrm{L}$ ratio. The $\mathrm{C} 400$ resulted a higher PCV count, percentage of heterophil, and $\mathrm{H} / \mathrm{L}$ ratio. The $\mathrm{C} 600$ produced the highest leucocyte count. In conclusion, the supplementation of ascorbic acid at $400-600 \mathrm{mg} / \mathrm{kg}$ feed ascorbic acid could improve the immune profile, but could not improve the performance of Muscovy duck.

Keywords: immunity, muscovy duck, tocopherol, ascorbic acid

\section{INTRODUCTION}

Indonesia climate with $20.4-36.8^{\circ} \mathrm{C}$ day temperature, $18.4-4.2^{\circ} \mathrm{C}$ of evening temperature and $55.3-85.8 \%$ of relative humidity (Badan Pusat Statistik, 20015) is not optimum for duck farming because this may induce stress in animal (El-Badry et al., 2009). High temperature resulted in restraint of the development of poultry immune organs. Heat stress stimulates the release of corticosterone and catecholamines and initiate lipid peroxidation in cell membranes. $\alpha$ Tocopherol supplementation is very effective for poultry because this may reduce the negative effects of corticosterone induced stress (Puthpongsiriporn et al., 2001). $\alpha$-Tocopherol and ascorbic acid supplementations in diet, particularly in a combination, alleviates the counterproductive effects of high ambient temperature and humidity on the birds (Ajakaiye et al., 2010). They are protective agent that deactivates reactive oxygen species (ROS) and significantly prevent oxidative damage (Ramnath et al., 2008; Prisyanto et al., 2014). $\alpha$-Tocopherol and ascorbic acid as an external antioxidant enhances an enzymatic and non-enzymatic antioxidant in preventing the free radical formation (Chevion et al., 2003).

$\alpha$-tocopherol prevents the formation of free radicals by donating hydrogen ions, thus forming vitamin $\mathrm{E}$ radical. Furthermore enadiol and hydrogen at $\mathrm{C} 2$ and $\mathrm{C} 3$ of ascorbic acid serve as an electron donor to vitamin $\mathrm{E}$ radical, thus vitamin $\mathrm{E}$ in turn can function as an antioxidant. Ascorbic acids supplies electron to intracellular and extracellular biochemical activity and removes reactive oxygen in cell. Ascorbic acid deficiency results in decreased immune response, depressed response to mitogenic, disturbed immunoglobulin metabolism, depressed $\mathrm{T}$ lymphocyte responses and antibody production (Ramnath et al., 2008).

Accordingly, a welfare disorder in the duck is observable from three indicators - physiology, production and immune system (McGrath et al., 2010; Lawrence and Stott, 2009). Body weight, feed intake and feed conversion are the visible growth performance indicator in Muscovy duck (Ogunwole et al., 2013). Blood is an important component to organize body physiology and serves as a fowl health indicator (Syahruddin et al., 2013; El-Badry et al., 2009). A good blood profile will support better physiology. Sejian et al. (2011) stated that animal welfare involves adaptations of normal physiology and behaviour leading to health status that ultimately increases productivity. Leucocyte is part of the immune system against several infectious diseases, while erythrocyte determines physiology. Leucocyte can move freely, interact and capture cellular debris, foreign material or intruding microorganism. Total plasma protein in blood is $7.2-8 \mathrm{~g} / \mathrm{dL}$ or $7 \%$ of whole blood and only $2-3 \%$ of total body protein (Ismoyowati et al., 2006) having multi-function, such as circulating lipid molecule, hormone, vitamin and zinc, enzyme, complement components, protease inhibitor and regulating activity of non cellular functional in the immune system (Moyes and Schulte, 2008). Packed cell volume (PCV) is the percentage of cell content in blood. PCV measures erythrocyte percentage in whole blood volume. PCV is erythrocyte fraction described in percent of all blood (Gandasoebrata, 2004). The purpose of this research was to assess the effect of $\alpha$-tocopherol and ascobic acids on performance and immunity blood profile of native male Muscovy duck.

\section{MATERIALS AND METHODS}

A total of eighty four male Muscovy ducks aged at 8 weeks old were given feed with $21 \%$ protein and $3100 \mathrm{kcal} / \mathrm{kg} \mathrm{ME} \mathrm{(Table} \mathrm{1).} \mathrm{The} \mathrm{birds}$ were assigned in 28 litter cage sized $2 \times 1 \mathrm{~m}^{2}$. The cage was provided with feeders and drinkers, scale and thermometer. All birds had regular medicine and vaccines. 
Table 1. Composition and Nutrients Content of Basal Treatment Diet

\begin{tabular}{lrlc}
\hline Feed ingredient & \multicolumn{1}{c}{$\%$} & \multicolumn{1}{c}{ Calculated Nutrient } & Amount \\
\hline Corn & 30.00 & Crude protein $\left.(\%)^{*}\right)$ & 21.02 \\
Soybean Meal & 7.00 & ME (kcal/kg) $)^{*}$ & 3103 \\
Rice bran & 38.20 & Extrat ether $(\%)^{*}$ & 5.73 \\
Poultry Meat Meal & 17.00 & Crude fiber $\left.(\%)^{*}\right)$ & 5.53 \\
Oil & 6.10 & $\mathrm{Ca}(\%)$ & 0.94 \\
CaCO3 & 1.00 & $\mathrm{P}_{\text {av }}(\%)$ & 0.56 \\
Topmix & 0.20 & Lysine $(\%)$ & 1.11 \\
NaCl & 0.10 & Metionine $(\%)$ & 0.64 \\
L-lysine $\mathrm{HCl}$ & 0.10 & Methionine + cystine $(\%)$ & 0.65 \\
DL-Methionine & 0.30 & & \\
Total & 100.00 & & \\
\hline
\end{tabular}

The experimental research was allocated to completely randomized design. Seven treatments were E0C0 : the basal diet without $\alpha$-tocopherol and ascorbic acids, E400: the basal diet $+\alpha-$ tocopherol 400IU, E600: the basal diet $+\alpha-$ tocopherol 600IU, C400: the basal diet + ascorbic acid $400 \mathrm{mg} / \mathrm{kg}$, C600: the basal diet + ascorbic acid $600 \mathrm{mg} / \mathrm{kg}$, E200C200: the basal diet $+\alpha-$ tocopherol $200 \mathrm{IU}+$ ascorbic acid $200 \mathrm{mg} / \mathrm{kg}$, and E300C300: basal diet $+\alpha$-tocopherol 300IU + ascorbic acid $300 \mathrm{mg} / \mathrm{kg}$. The muscovy ducks were randomly placed in four replicates with 3 ducks of each per group in litter cage. Data were tested using analysis of variance followed by honestly significant difference test. The observed variables were body weight, feed consumption, feed conversion ratio, packed cell volume (PVC), leucocyte count, heterophil percentage, eosinophils percentage, lymphocytes percentage and monocytes percentage, heterophil/lymphocyte $(\mathrm{H} / \mathrm{L})$ ratio. In each bird, body weight was measured weekly and feed intake was recorded daily.

Blood sample of Muscovy duck was taken at 14 weeks old for hematology analysis. Body weight was recorded weekly and feed conversion was calculated daily. Blood sampling was carried out by a veterinarian and in conformity with that taken from the brachial vein. The blood sampling was in accordance with the ethics code of Indonesian Veterinarian and the Laws of the
Republic of Indonesia No. 18, 2009 on Animal Husbandry and Animal Health those obtained a certificate of eligibility of animal conduct (Animal Ethical Clearence) No 282540009/3/2013. PCV analysis was conducted by aspirating blood up to $1 \mathrm{~cm}$ from the top end using Hawkslay. Capillary tube was clogged with crystal seal, wax or soap, then placed in micro centrifuge in open capillary end center-faced and centrifuged for 5 minutes at 12.000 RPM, after which the capillary pipe was taken out to read PVC value using hematocrit reader. Refractometer hand was used to count blood Total Plasma Protein. One or two drops of the separated/centrifuged serum or blood plasma was put on the plate and pressed with a plastic lid to see the amount of total plasma protein in gram at certain scales.

Leucocyte count started by blood dilution with a Turk solution in leucocyte pipe then put in counting chamber (Nugroho, 2013). The investigation was as follows: a) capillary blood, EDTA blood or oxalate blood was aspirated to 0,5 bars; b) blood droplets were discarded on pipette tip; c) The pipette tip was dipped into the Turk solution at $45^{\circ}$ angle and hold at 0.5 bars. The Turk solution was aspirated to 11 bars to avoid air bubble; d) pipette tip was covered by finger, then the rubber bulb was removed; e) shaking for 15-30 seconds; f) storing with lid on horizontally on the table inside the counting chamber; 
g) Pipette was shaken for 3 min to keep the fluid from spilling out; h) all fluids in capillary pipe were discarded (3-4 drops) and quickly tap pipette tip on counting chamber by touching the glass cover rim with $30^{\circ}$ angle. The fluid was filled with counting chamber with capillary pressure; i) leucocyte was left for 2-3 minutes until settle; j) objective microscope lens was used with 10x magnification, focusing on the bisecting lines; $\mathrm{k}$ ) leucocyte was counted in four big area from upper left to right, bottom to left, bottom to left and so on. Cells in line were counted from left and upper lines; 1) total leucocyte per $\mu \mathrm{L}$ blood was-cell count.

\section{RESULTS AND DISCUSSION}

\section{Muscovy Duck Performance}

The high and low of duck meat production was significantly affected by physiological performance. The observed performance indicator was fed intake, body weight and feed conversion. The treatments of E0C0, E400, E600, C400, C600, E200C200 and E300C300 resulted in higher body weight than the control. The highest body weight of Muscovy duck in the research $(2357.50 \pm 85.78 \mathrm{~g})$ was reached by C400, but analysis of variance result showed that they did not significantly affect $(\mathrm{P}>0.05)$ on body weight, feed intake and feed conversion of 14 week old male Muscovy duck (Table 2). These results agree with studies of In agreement with results of Schiavone et al., (2010) and Marzoni et al.,
(2014). They found that the performances of Muscovy duck (live body weight at 63 days, feed consumption and feed conversion ratio) were not influenced by dietary treatments of $20 \mathrm{~kg}$ soybean oil $+30-230 \mathrm{mg} / \mathrm{kg} \alpha$-tocopheryl acetate and natural antioxidant supplementation.

Surai et al. (2003) reported that $\alpha$-tocopherol and ascorbic acid and its combination improve body vitality as proven by zero mortality or disease occurance in duck during research period and the increased hemoglobin compared to control, however this could not trigger hunger center in hypothalamus so that Muscovy duck consumed more feed.

\section{Packed Cell Volume (PCV) and Total protein Plasma (TPP)}

The observed physiological indicator was PCV and TPP. Blood is essential for physiological process in fowl, mainly for enzyme activity and hormone synthesis, and hormone concentration in plasma will affect productivity (Ismoyowati et al., 2006).

Supplementation of $\mathrm{C} 400$ in feed tended to increase the values of PCV and TPP. The lowest PCV was reached by E0C0 and the lowest of TPP was reached by E200C200 (Table 3). The result of variance analysis showed that E0C0, E400, E600, $\mathrm{C} 400, \mathrm{C} 600, \mathrm{E} 200 \mathrm{C} 200$ and $\mathrm{E} 300 \mathrm{C} 300$ significantly affected $(\mathrm{P}<0.05)$ the $\mathrm{PCV}$ percentage, but had no significant effect on protein plasma level of a 14 week old male duck (Table 3). There was a different $(\mathrm{P}<0.05)$ in $\mathrm{PVC}$

Table 2. Body Weight, Feed Consumption, FCR of Muscovy Duck Aged 14 Weeks Old Feed $\alpha-$ Tocopherol and Ascorbic Acid

\begin{tabular}{lccc}
\hline \multicolumn{1}{c}{ Treatments } & $\mathrm{BW}(\mathrm{g})^{\mathrm{ns}}$ & $\mathrm{FC}(\mathrm{g})^{\mathrm{ns}}$ & FCR $^{\mathrm{ns}}$ \\
\hline E0 C0 & $2210.42 \pm 79.68$ & $9018.50 \pm 157.12$ & $4.08 \pm 0.23$ \\
E 400 & $2280.76 \pm 144.32$ & $9396.75 \pm 280.15$ & $4.12 \pm 0.22$ \\
E 600 & $2264.69 \pm 45.07$ & $9398.50 \pm 114.51$ & $4.15 \pm 0.17$ \\
C 400 & $2357.50 \pm 85.78$ & $9170.68 \pm 240.37$ & $3.89 \pm 0.11$ \\
C 600 & $2288.68 \pm 264.19$ & $9360.75 \pm 198.29$ & $4.09 \pm 0.18$ \\
E200C200 & $2358.46 \pm 81.29$ & $9481.00 \pm 134.67$ & $4.02 \pm 0.30$ \\
E 300C 300 & $2248.70 \pm 94.84$ & $9039.75 \pm 159.55$ & $4.02 \pm 0.22$ \\
\hline
\end{tabular}

$\mathrm{BW}=$ body weight, $\mathrm{FC}=$ Feed consumption, $\mathrm{FCR}=$ Feed Conversion Ratio $(9-14$ weeks old $)$, ${ }^{\text {ns }}$ Means without superscripts in the same column is not differ significantly ( $>0.05)$ 
Table 3. PVC and TPP level of Muscovy Duck Aged 14 Weeks Old Feed $\alpha$-Tocopherol and Ascorbic Acid

\begin{tabular}{lcc}
\hline Treatments & PCV $(\%)^{*}$ & TPP $(\mathrm{d} / \mathrm{dl})^{\mathrm{ns}}$ \\
\hline E0 C0 & $36.25 \pm 0.50^{\mathrm{a}}$ & $3.70 \pm 0.38$ \\
E 400 & $42.00 \pm 4.08^{\mathrm{ab}}$ & $3.80 \pm 0.23$ \\
E 600 & $41.00 \pm 4.24^{\mathrm{ab}}$ & $3.75 \pm 0.10$ \\
C 400 & $44.25 \pm 2.22^{\mathrm{cb}}$ & $4.50 \pm 1.18$ \\
C 600 & $42.50 \pm 2.38^{\mathrm{ab}}$ & $4.15 \pm 0.86$ \\
E200C 200 & $41.50 \pm 2.65^{\mathrm{ab}}$ & $3.55 \pm 0.53$ \\
E 300C 300 & $40.25 \pm 3.59^{\mathrm{ab}}$ & $3.70 \pm 0.80$ \\
\hline
\end{tabular}

$\mathrm{PCV}=$ Packed Cell Volume,TPP $=$ Total Protein Plasma, ${ }^{\text {ns }}$ Means without superscripts in the same column is not differ significantly ( $>0.05) ; *$ Means with different superscripts in the same column is differ significantly $(\mathrm{p}<0.05)$

value between control and $\mathrm{C} 400$ treatments. The $\mathrm{PCV}$ value of Muscovy duck in the research was lower than Muscovy duck in southeastern Nigerian $(46.00 \pm 1.73)$ from Okeudo et al. (2003). Ismoyowati et al. (2012) stated that PCV and total plasma protein level during dry season was lower than that in the wet season. This indicated that environmental factors, namely temperature and humidity strongly influenced the duck's physiology..

Supplementation of ascorbic acid at 400 $\mathrm{mg} / \mathrm{kg}$ feed attributed to the increased absorption of $\mathrm{Fe}$ and $\mathrm{Cu}$ as the main components of red blood cell. Ascorbic acid inhibits hemosiderin formation that is less mobilezable to free $\mathrm{Zn}$ when needed. Ascorbic acid in feed would induce an acidic condition, thus reducing ferric to more absorbable ferrous in the small intestines. Absorption of non heme iron is quadruple owing to ascorbic acid (Adriani and Wirjatmadi, 2012).

PCV or hematocrit highly depends on erythrocyte count, because erythrocyte is the biggest cell mass of blood. PCV value rise and fall affects blood viscosity, the higher PCV percentage more red blood cell produced, and ascorbic acid boosts iron sufficiency and absorption, so that animals are free from anemia (Winarsi et al., 2005). Plasma proteins consist of albumin, globulin and fibrinogen and they play a crucial role in maintaining homeostasis. These proteins have multiple functions; albumin is the most abundant and osmotically active plasma protein, and it is an important carrier of many substances in the peripheral circulation. Globulins are classified on the basis of their electrophoretic mobility as alpha-, beta- and gamma-globulins. While fibrinogen is important in blood clot formation, thereby preventing loss of blood from a ruptured blood vessel. The decreasing total protein concentration is due to the progressive albumin increase and globulin decrease (Harvey, 2001; Nelson and Cox, 2008). This indicated the well-functioning transport of bilirubin, thyroid hormone, cytoskeletal components, extracellular compounds and as protein carrier.

The use of plasma in biochemistry and hematology is for monitoring the health conditions of birds. It is also useful for distinguishing pathogenic processes from those that might be purely physiological (Ortizo et al., 2014). Albumin serves as the major amino acid pool, the catabolism of albumin provides protein precursors needed for growth or other physiological needs. The high performance of production has a low of total plasma protein (Wang et al., 2013). Plasma proteins are the key components of plasma and they play a crucial role in maintaining homeostasis (Yaqub et al., 2013).

\section{Immune Profile}

Hematological and plasma biochemical profiles provide reliable information on the health status of poultry (Ismoyowati et al., 2012). Table 4 showed that supplementing $\alpha$-tocopherol, ascorbic acid and their combined did not significantly affected on monocyte and eosinophil percentage and $\mathrm{H} / \mathrm{L}$ ratio of duck., but significantly affected total leucocyte count, heterophil percentage, and lymphocyte percentage.

Leucocyte count of control group was significantly differed $(\mathrm{P}<0.05)$ with E600, C400, E200C200 and C600 groups (Table 4). This result was in line with Selim et al. (2012) that $10 \mathrm{mg} \alpha$ tocopherol and $3 \mathrm{mg}$ ascorbic acid are very effective on humoral immunity and immune cells of Muscovy ducks. The immune system required antioxidants produce and maintained the balance of immune cells (haematopoesis), protects cell membranes from ROS, to fight microorganisms caused disease. Ascorbic acid affects the immune system by stimulating neutrophils and macrophage function, thus increasing chemotaxis and mobility, enhancing phagocytosis and 
Table 4. Immune Profile of Muscovy Duck Aged 14 Weeks Old Feed $\boldsymbol{\alpha}$-Tocopherol and Ascorbic Acid

\begin{tabular}{|c|c|c|c|c|c|c|}
\hline Treatments & $\begin{array}{l}\text { Leukocyte } \\
\text { count } \\
(\text { cell. } / \mu 1)^{\mathrm{ns}}\end{array}$ & $\begin{array}{l}\text { Heterophyls } \\
(\%)^{*}\end{array}$ & $\begin{array}{c}\text { Eosinofil } \\
(\%)^{\mathrm{ns}}\end{array}$ & $\begin{array}{l}\text { Limfosit } \\
(\%)^{*}\end{array}$ & $\begin{array}{c}\text { Monosit } \\
(\%)^{\mathrm{ns}}\end{array}$ & Rasio $\mathrm{H} / \mathrm{L}^{\mathrm{ns}}$ \\
\hline E0 C0 & $9,650.00^{\mathrm{a}}$ & $17.25^{\mathrm{a}}$ & 16.50 & $40.75^{\mathrm{a}}$ & 14.50 & 0.42 \\
\hline E 400 & $13,312.50^{\mathrm{a}}$ & $28.75^{\mathrm{a}}$ & 14.00 & $64.25^{\mathrm{b}}$ & 14.25 & 0.45 \\
\hline E 600 & $15,112.50^{\mathrm{b}}$ & $29.75^{b}$ & 1850 & $55.00^{\mathrm{a}}$ & 15.00 & 0.54 \\
\hline C 400 & $15,725.00^{\mathrm{b}}$ & $31.50^{\mathrm{b}}$ & 12.75 & $55.00^{\mathrm{a}}$ & 6.00 & 0.57 \\
\hline C 600 & $17,387.50^{\mathrm{b}}$ & $30.00^{\mathrm{b}}$ & 13.50 & $66.75^{\mathrm{b}}$ & 10.75 & 0.45 \\
\hline E200C200 & $14,925.00^{\mathrm{b}}$ & $30.75^{b}$ & 9.25 & $69.00^{\mathrm{b}}$ & 12.25 & 0.45 \\
\hline E $300 C 300$ & $13,437.50^{\mathrm{a}}$ & $31.25^{\mathrm{b}}$ & 11.00 & $60.75^{\mathrm{a}}$ & 18.50 & 0.51 \\
\hline
\end{tabular}

${ }^{n s}$ Means without superscripts in the same column is not differ significantly ( $\left.>0.05\right)$; * Means with different superscripts in the same column is differ significantly $(\mathrm{p}<0.05)$

enhance the ability of killing bacteria (Wintegrest et al., 2007). $\alpha$-Tocopherol has a role as an immunomodulator, increases lymphocyte proliferation and promote the cytokine production (Lee and Wan, 2000). $\alpha$-Tocopherol, may also inhibit the activity of protein kinase $\mathrm{C}$ involved in cell proliferation and differentiation of cells in smooth muscle cells, platelets, and monocytes (Chandra, 2002). Lawhead and Baker (2005) stated that total count and type of leucocyte help to diagnose animal condition or infectious status. High leucocyte count may indicate high immunity in ducks and fast eliminating infection. Total leucocyte count in Muscovy duck in this research was $9650 \pm 1984.10-17387.50 \pm 835.04($ cells $/ \mu \mathrm{l})$, relatively similar with Kabir (2012).

Heterophyl percentage of C600, C400, $\mathrm{E} 200 \mathrm{C} 200$ and $\mathrm{E} 300 \mathrm{C} 300$ groups were significantly differed $(\mathrm{P} 0<0.05)$ with the control and E600 groups (Table 4). Table 4 also shows that lymphocyte percentage of C600 group was significantly differed $(\mathrm{P}<0.05)$ with $\mathrm{E} 400$, E600, C400, E300C300 and control groups. Lymphocyte percentage of E200C200 group was significantly differed $(\mathrm{P}<0.01)$ with E400 and E600 groups, $\mathrm{C} 400$ and E300C300 groups. The lymphocyte percentage of E0C0 group was higher $(\mathrm{P}<0.01)$ than that of $\mathrm{C} 600$ group. These results showed that supplementing $\alpha$-tocopherol and ascorbic acid improve the immune system by increasing lymphocyte count. Lymphocyte produces antibody to help disease prevention (Lawhead and
Baker 2005), because $\alpha$-tocopherol produces interleukin-2 that improves body immune, prevents disease and accelerates recovery, while ascorbic acid actively rejuvenates germ-killing cells, helps the production of interferon that kills the virus in the body and increases glutathione in the body (Surai et al., 2003).

The $\mathrm{H} / \mathrm{L}$ ratio was not affected by the supplementation treatments (Table 4). This was because $\alpha$-tocopherol and ascorbic acid increased the amount of heterophil and lymphocyte that improved ducks immunity. Furthermore, $\alpha$ tocopherol and ascorbic acid improve phagocyte activity by increasing lymphocyte count and preventing a decrease in hemoglobin, leucocyte and thrombocyte (Prisyanto et al., 2014). Ismoyowati et al. (2012) stated that the fowl comfort may be indicated by measuring the H/L ratio. The $\mathrm{H} / \mathrm{L}$ ratio is more liable as a fowl comfort than blood corticosterone level. McGrath et al. (2010) stated that fowl in a good welfare or normal physiological condition is indicated with a lower $\mathrm{H} / \mathrm{L}$ value than that of distress environment. Ismoyowati (2007) reported that highly productive local duck has an average $\mathrm{H} / \mathrm{L}$ ratio of $0.417 \pm 0.125$

\section{CONCLUSION}

Supplementing 400-600 mg/kg feed ascorbic acid improve the blood immune profile, but could not improve the performance of Muscovy duck. 


\section{ACKNOWLEDGEMENT}

Sincerest gratitude goes to Directorate General of Higher Education and Department of Animal Science of Jenderal Soedirman University for the completion of post graduate study.

\section{REFERENCES}

Adriani, M. and B. Wirjatmadi. 2012. Pengantar Gizi Masyarakat. Cetakan Ke-1. Kencana Prenada Media Group. Jakarta.

Ajakaiye, J. J., A. Pérez-Bello, M. CuestaMazorra, J.R. García-Díaz and A. Mollineda-Trujillo. 2010. Effects of vitamin $\mathrm{C}$ and $\mathrm{E}$ dietary supplementation on erythrocyte parameters of layer chickens reraed in high ambient temperature and humidity. Brazilian J. Poult. Sci. 12(3):205209.

Chandra, R. K. 2002. Influence of micronutrient supplement on immune responses and infection-related illness in 50-65 year old individuals. Nut. Res. 22:5-11.

Chevion, S., D. S. Moran, Y. Heled, Y. Shani, G. Regev, B. Abbou, E. Berenshtein, E. R. Stadtman and Y. Epstein. 2003. Plasma antioxidant status and cell injury after severe physical exercise. Proc. Natl. Acad. Sci. USA. 100(9): 5119-5123.

El-Badry, A.S.O., M.M. Hassanane, E.S. Ahmed and K.H. El-Kholy. 2009. Effect of earlyage acclimation on some physiological, immunological responses and chromosomal aberrations in muscovy ducks during exposure to heat stress. Global J. Biotechnol. Biochem. 4(2):152-159.

Gandasoebrata, R. 2004. Penuntun Laboratorium Klinik. Ed. 11, Dian Rakyat, Jakarta.

Harvey, J. W. 2001. Atlas of Veterinary hematology: Blood and Bone Marrow of Domestic Animals. W B. Saunders, Philadelphia USA.

Badan Pusat Statistik. 2015. Statistik Indonesia 2015: Keadaan Iklim. Badan Pusat Statistik. Jakarta

Ismoyowati., T. Yuwanta., J. Sidadolong and S. Keman. 2006. Performans reproduksi iti Tegal berdasarkan status hematologis. Anim. Prod. 8(2):88-93

Ismoyowati. 2007. Deteksi Hematologis dan Polimorfisme Protein Darah sebagai Dasar Seleksi pada Pemurnian Itik Tegal. Dissertation. Gadjah Mada University,
Yogyakarta.

Ismoyowati, M Samsi and M Mufti. 2012. Different haematological condition, immune system and comfort of Muscovy duck and local duck reared in dry and wet seasons. Anim. Prod. 14(2):111-117.

Kabir, M. A. 2012. Haematological studies in chicken and a group of birds. Intl. J. Med. Appl. Sci. 1(1):30-38.

Lawhead, J. B. dan M. Baker. 2005. Introduction to Veterinary Science. Thomson and Learning, Australia.

Lawrence, A. B. and A.W. Stott. 2009. Profiting From Animal Welfare: An Animal-Based Perspective. The Oxford Farming Conference. Scottish Agricultural College

Lee, C.Y. and J. Man-Fan Wan. 2000. Vitamin E supplementation improves cell mediates immunity and oxidative stress of Asian men and women. J. Nutr. 130: 2932-2937.

Marzoni, M., R Chiarini, A. Castillo, I. Romboli, Michele De Marco, A. Schiavone. 2014. Effects of dietary natural antioxidant supplementation on broiler chicken and Muscovy duck meat quality. Anim. Sci. Papers and Reports. 32 (4):359-368

McGrath, J.C., G.B. Drummond, E.M. McLachlan, C. Kilkenny and C.L. Wainwright. 2010. Guidelines for reporting experiments involving animals: the ARRIVE guidelines. Br. J. Pharmacol. 160:1573-1576.

Moyes, C.D. and P. M. Schulte. 2008. Principles of Animal Physiology. 2nd Ed. Perarson International Edition, New York.

Nelson, D.L. and M. M. Cox. 2008. Lehninger Principles of Biochemistry. 5th Edition. W.H. Freeman and Company. New York.

Nugroho, H.S.W. 2013. Laboratorium Klinik: Pemeriksaan Hematology. Gadjah Mada University Press, Yogyakarta.

Ogunwole, O. A., Y. A. A. Oso, R. R.Omotoso, B. C. Majekodunmi, B. O. Ayinde and I. Oikeh. 2013. Performance, carcasscharacteristics and meat physicochemical properties of broiler chickens fed graded levels of supplemental ascorbic acid. Agric. Biol. J. North America. 4(4):485-495

Okeudo, N..J, I.C. Okoli and G.O.F. Igwe. 2003. Hematological Characteristics of ducks (Cairina moschata) of Southeastern Nigeria. Tropicultura. 21 (2):61-65.

Okonkwo J.C, J.S. Omeje and I.F. Okonkwo. 2011. Effect of source and sex on blood protein fractions of West African dwarf 
goats (WADG). Res. Opin. Anim. Vet. Sci. 1(3):158-161

Ortizo, K.A. A.R. Cuyacot, J. J. M. Mahilum, H.I. Rivero and O.M. Muneza. 2014. Plasma biochemistry levels and hematological parameter in Mallard Ducks (Anas platyrhynchos Linn) from selected semifree range Duck Farms in Misamis Occidental and Zamboanga Del Sur Philipines. Anim. Biol. Anim. Husbandry Bioflux. 6(1):51-62.

Prisyanto, R. D.R. Santoso, U.P. Juswono and Y.Cahyati. 2014. Effect of combined Vitamin $\mathrm{E}$ and $\mathrm{C}$ supplementation on total hemoglobin, leukocyte, thrombocyte post gamma radiation. J. Health Env. Sci. 2(3):289-295.

Puthpongsiriporn, U., S. E. Scheideler, J. L. Sell, and M. M. Beck. 2001. Effects of Vitamin E and $\mathrm{C}$ supplementation on performance, In vitro lymphocyte proliferation, and antioxidant status of laying hens during heat stress. Poult.Sci. 80:1190-1200

Ramnath, V., P.S. Rekha and K.S. Sujatha. 2008. Amelioration of heat stress induced disturbances of antioxidant defense system in chicken by brahma rasayana. Evid. Based Complement. Alternative Med. 5(1):77-84

Schiavone, A. , M. Marzoni, A. Castillo, J. Nery and I. Romboli. 2010. Dietary lipid sources and vitamin $\mathrm{E}$ affect fatty acid composition or lipid stability of breast meat from Muscovy duck. Can. J. Anim. Sci. 90: 371378.

Sejian, V. J. Lakritz, T. Ezeji and R. Lal. 2011.
Assesment method and indicators of animal welfare. Asian J. Anim. and Vet. Adv. 6(4): 301-315.

Selim, S.A., K. M. Gaafar and S. S. El-ballal. 2012. Influence of in-ovo administration with vitamin $\mathrm{E}$ and ascorbic acid on the performance of Muscovy ducks. Emir. J. Food Agric. 24(3): 264-271

Surai, P.F. F. Karadas and N.H. Sparks 2003. The Importance of Antioxidants in Poultry. Avian Science Research Centre, SAC, Auchincruive, Ayr, Scotland, UK and Department of Animal Science, Yuzuncu Yil University, Turkey.

Syahruddin, E., R. Herawaty and Yoki. 2013. Pengaruh vitamin $\mathrm{C}$ dalam kulit buah nanas (Ananas comosus L. Merr) terhadap hormon tiroksin dan anti stres pada ayam broiler di daerah tropis. J. Ilmu Ternak Vet. 18(1):1726

Wang, C.K, Y.W. Hua. Chen, L.H. Xu, L.Q. Xie, Q.D. Chen and G.J. He. 2013. Effect of different protein levels on growth performance, carcass characteristic and blood parameters of Cherry Valley duck. J. Anim. Vet. Advances. 12(21):1605-1609

Winarsi, H., D. Muchtadi, F. R. Zakaria and A. Purwanto. 2005. Efek suplementasi Zn terhadap status imun wanita premenopause yang diintervensi dengan minuman berisoflavon. Hayati. 12(2):82-86

Yaqub, L. S., M. U. Kawu and J. O. Ayo. 2013. Influence of reproductive cycle, sex, age and season on haematologic parameters in domestic animals: A review. J. Cell Anim. Biol. 7(4): 37-43 